\title{
阳离子表面活性剂-阴离子聚合物为模板剂合成硅基介孔材料
}

\author{
张莉娜 ${ }^{1,2}$, 王 浩 ${ }^{1}$, 㚞卫斌 ${ }^{1, \mathrm{a}}$, 王建国 ${ }^{1, \mathrm{~b}}$ \\ 1中国科学院山西煤炭化学研究所煤转化国家重点实验室, 山西太原 030001 \\ $2^{2}$ 中国科学院研究生院, 北京 100049
}

\begin{abstract}
摘要: 以阳离子表面活性剂十六烷基三甲基溴化铵和阴离子水溶性聚丙烯酸钠 (NaPAA) 混合物为模板剂, 在较高温度和碱度 下采用 Stöber 法合成介孔材料. 通过调变助剂乙醇含量、晶化温度、晶化时间、NaPAA 含量和分子量等制得结构和形貌不同 的硅基介孔材料. 研究表明, 这是 NaPAA 和乙醇共同作用的结果.
\end{abstract}

关键词: 阳离子表面活性剂; 阴离子聚合物; 复合模板剂; 乙醇; 硅基介孔材料

中图分类号: O643 文献标识码: A

收稿日期: 2011-08-12. 接受日期: 2011-10-15.

a通讯联系人. 电话: (0351)4199009; 传真: (0351)4041153; 电子信箱: fanwb@sxicc.ac.cn

b通讯联系人. 电话: (0351)4199009; 传真: (0351)4041153; 电子信箱: iccjgw@sxicc.ac.cn

基金来源: 中国科学院山西煤炭化学研究所煤转化国家重点实验室 (2010BWZ002).

本文的英文电子版(国际版)由Elsevier出版社在ScienceDirect上出版(http://www.sciencedirect.com/science/journal/18722067).

\section{Synthesis of Mesoporous Silicas with a Cationic Surfactant-Anionic Polymer Mixture as Template}

\author{
ZHANG Lina $^{1,2}$, WANG Hao ${ }^{1}$, FAN Weibin ${ }^{1, \mathrm{a}}$, WANG Jianguo ${ }^{1, \mathrm{~b}}$ \\ ${ }^{1}$ State Key Laboratory of Coal Conversion, Institute of Coal Chemistry, Chinese Academy of Sciences, Taiyuan 030001, Shanxi, China \\ ${ }^{2}$ Graduate University of Chinese Academy of Sciences, Beijing 100049, China
}

\begin{abstract}
Different structural mesoporous silicas have been synthesized at high temperature using the Stöber method by utilizing a mixture of cationic cetyltrimethylammonium bromide and anionic water-soluble sodium polyacrylate (NaPAA) as template. The synthetic conditions, which include the amount of ethanol, crystallization temperature, crystallization time, polymer concentration, and molecular weight, have significant influence on the structures and surface morphologies of the synthetic product. This could be attributed to a combined effect of NaPAA and ethanol.
\end{abstract}

Key words: cationic surfactant; anionic polymer; composite template; ethanol; mesoporous silica

Received 12 August 2011. Accepted 15 October 2011.

${ }^{a}$ Corresponding author. Tel: +86-351-4199009; Fax: +86-351-4041153; E-mail: fanwb@sxicc.ac.cn

${ }^{b}$ Corresponding author.Tel: +86-351-4199009; Fax: +86-351-4041153; E-mail: iccjgw@sxicc.ac.cn

This work was supported by the State Key Laboratory of Coal Conversion (2010BWZ002).

English edition available online at Elsevier ScienceDirect (http://www.sciencedirect.com/science/journal/18722067).

自 $\mathrm{M} 41 \mathrm{~S}^{[1,2]}$ 介孔材料被合成以来, 因其具有较 大的比表面积和孔体积以及可调的孔尺寸和均匀的 孔径分布而被广泛应用于吸附分离、催化、生化、 色谱填料和药物传输等领域 ${ }^{[3 \sim 7]}$. 介孔材料的性能 不仅与其内在的孔道结构有关, 更与其宏观形态和
微观形貌密切相关. 表面活性剂结构和合成条件是 影响介孔材料孔道结构、有序度和形貌的关键因素. 因此, 模板剂的优选和反应条件的调控一直是介孔 材料合成研究的重点. 到目前为此, 大多数研究工 作主要集中在以传统的阴、阳离子和中性表面活性 
剂为模板剂合成有序介孔材料. 虽然传统表面活性 剂种类繁多, 但能起模板作用的却不多 ${ }^{[3]}$, 这在一定 程度上限制了硅基介孔材料的广泛应用. 因此, 寻 找新的模板剂和拓宽介孔材料的合成方法广受关 注. 单一共聚物 ${ }^{[8 \sim 11]}$ 、复合共聚物 ${ }^{[12]}$ 、天然共聚 物 ${ }^{[13]}$ 、共聚物-表面活性剂复合物 ${ }^{[14,15]}$ 、Gemini 表 面活性剂 ${ }^{[16]}$ 、氟碳表面活性剂 ${ }^{[17]}$ 和手性醇 ${ }^{[18]}$ 等均被 用来制备介孔材料. 另外, 多种辅助剂, 如乙醇、异 丙醇、乙醚和丙酮等, 也被引入到合成体系中, 以调 控介孔材料的结构和形貌 ${ }^{[16,19 ~ 21]}$.

阴离子水溶性聚合物聚丙烯酸 (PAA) 因具有较 强的亲水羰基基团而用于生物矿化过程 ${ }^{[22]}$. 研究表 明, 以 PAA 为阻碍剂, 通过与树形高分子聚氨基酰 胺共同作用可以合成无定形硅粒子 ${ }^{[23]}$. Guo 等 ${ }^{[20]}$ 在 室温利用 PAA 和十六烷基三甲基溴化铵 (CTAB) 混合物为模板剂, 在异丙醇-水溶液中, 通过调节 $\mathrm{PAA}$ 和 CTAB 的质量比, 得到表面腔洞可调的介孔 硅球, 但利用 PAA 合成有序介孔材料的报道较少. 本文以阳离子表面活性剂和阴离子水溶性高分子聚 合物的混合物为模板剂, 在高温通过添加溶剂乙醇 合成球形介孔材料, 并考察合成条件对产物形成与 性质的影响规律, 研究了球形介孔材料的形成机理.

\section{1 实验部分}

\section{1 介孔材料的合成}

将一定量的 CTAB (纯度 $\geqslant 99.0 \%$, 北京百灵威 科技有限公司) 加到含 $13.6 \mathrm{ml}$ 浓氨水 $(25 \%)$ 的水
溶液中 (摩尔比 $\mathrm{CTAB} / \mathrm{SiO}_{2}=0.13, \mathrm{NH}_{4}{ }^{+} / \mathrm{SiO}_{2}=7.3$, $\mathrm{H}_{2} \mathrm{O} / \mathrm{SiO}_{2}=130$ ), 于 $30^{\circ} \mathrm{C}$ 搅拌 $0.5 \mathrm{~h}$, 然后加入适量 $\operatorname{NaPAA}\left(M_{\mathrm{w}}=2100\right.$, 占合成溶胶总质量的 $\left.0 \sim 0.2 \%\right)$, 继续摚拌 $1 \mathrm{~h}$, 再加入一定量乙醇并搅拌 $0.5 \mathrm{~h}$, 最后 快速加入适量正硅酸乙酯 (TEOS), 并在 $30^{\circ} \mathrm{C}$ 摚拌 $1 \mathrm{~h}$, 形成均匀凝胶后升温至 $85^{\circ} \mathrm{C}$, 继续搅拌 $24 \mathrm{~h}$, 产物经过滤、洗涤和干燥后, 于 $550{ }^{\circ} \mathrm{C}$ 焙烧 $6 \mathrm{~h}$ 除去 有机模板剂. 依据乙醇加入的体积量将合成样品命 名为 $\mathrm{S}_{x}$, 其中 $x$ 为乙醇加入体积 $(\mathrm{ml})$.

\section{2 样品的表征}

以 Bruker D8 ADVANCE 型 X 射线衍射 (XRD) 仪测定样品的晶相, $\mathrm{Cu}$ 靶, $K_{\alpha}$ 辐射源 $(\lambda=0.154 \mathrm{~nm})$, 电压 $40 \mathrm{kV}$, 电流 $40 \mathrm{~mA}$, 扫描速度 $0.6 \% \mathrm{~min}$, 步长 $0.002^{\circ}$. 样品的高分辨透射电子显微镜 (HRTEM) 照 片在日本 JEOL-2100 型透射电子显微镜上得到. $\mathrm{N}_{2}$ 吸附-脱附等温线在 Belsorp Max 型吸附仪上测定. 测试前, 样品在 $300^{\circ} \mathrm{C}$ 真空处理 $6 \mathrm{~h}$. 比表面积采 用 BET 法计算, 孔径分布和孔体积采用 BJH 法计 算. 样品形貌在 Quanta $400 \mathrm{~F}$ 型场发射扫描电子显 微镜 $(\mathrm{SEM})$ 上观察.

\section{2 结果与讨论}

\section{1 乙醇含量对样品结构和形貌的影响}

图 1(a) 为不同乙醇添加量合成的样品经焙烧 后的 XRD 谱. 可以看出 $\mathrm{S}_{0}$ 和 $\mathrm{S}_{10}$ 样品除了在 $2 \theta=$ $2^{\circ}$ 附近出现一强衍射峰 (100) 外, 在 $2 \theta=4.1^{\circ}$ 和 $4.7^{\circ}$ 处也出现了 (110) 和 (200) 晶面衍射峰, 说明产物具
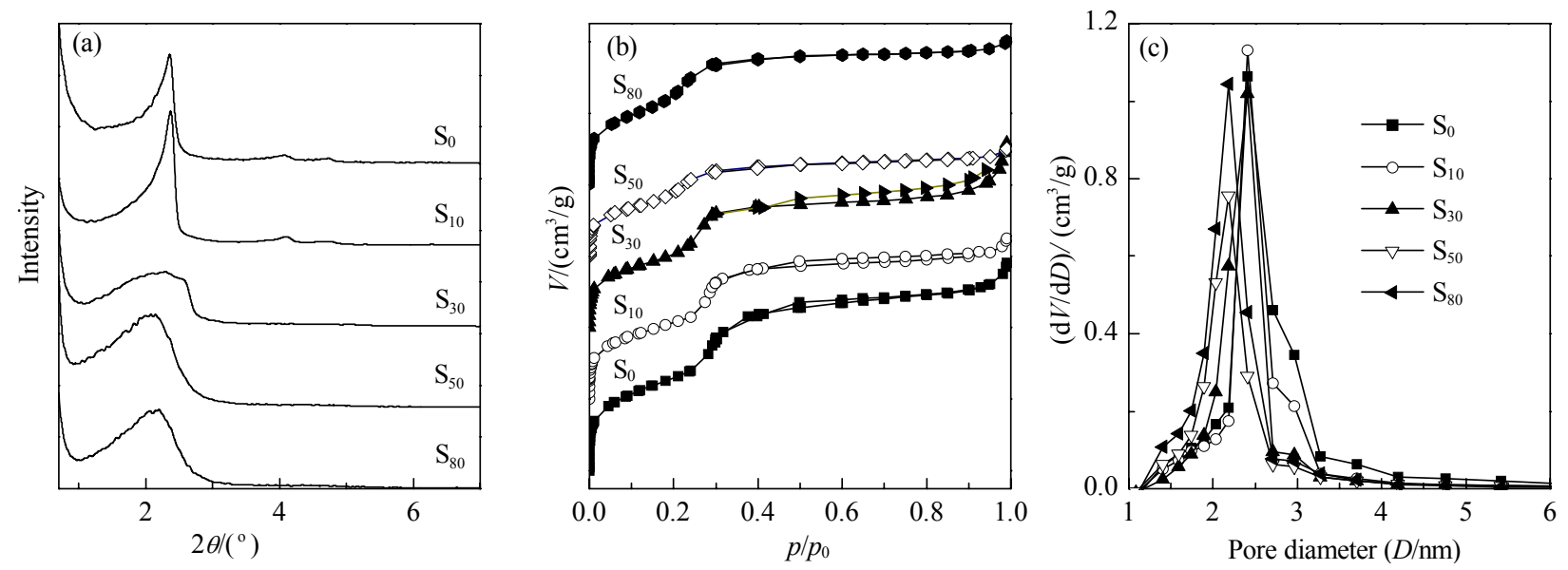

图 1 加入不同体积乙醇合成的硅基介孔材料样品的 XRD 谱 (a), $\mathrm{N}_{2}$ 吸附-脱附等温线 (b) 和孔径分布曲线 (c) Fig. 1. XRD patterns (a), $\mathrm{N}_{2}$ adsorption-desorption isotherms (b), and pore size distribution curves (c) of the mesoporous silica samples (denoted $\mathrm{S}_{x}$ ) synthesized with different amounts of ethanol $(x, \mathrm{ml})$. 

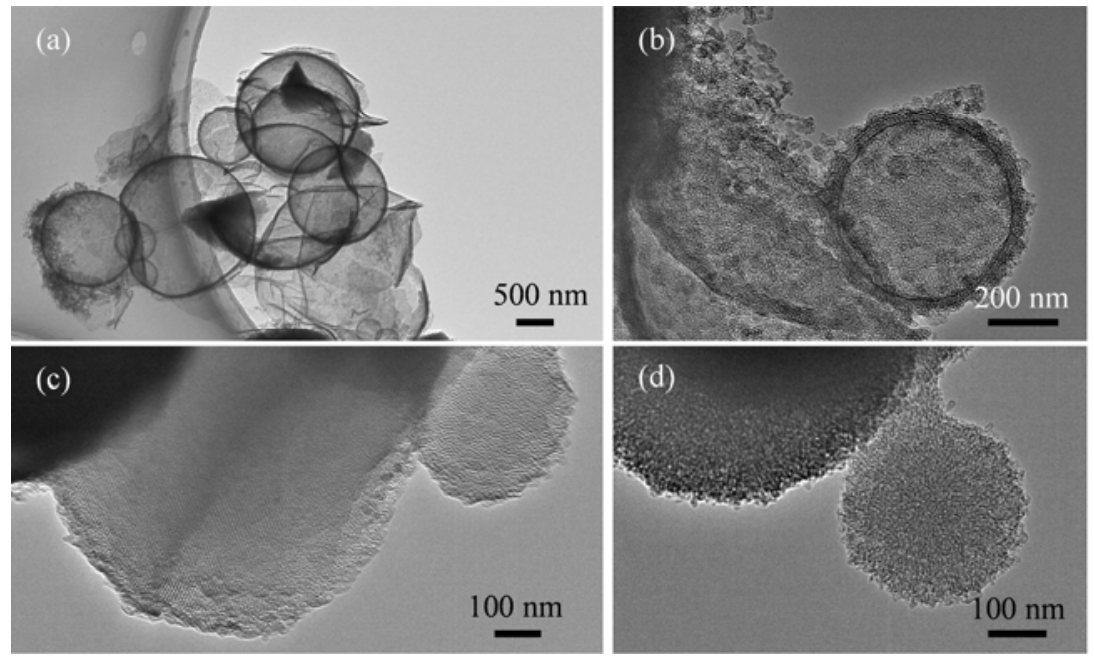

图 $2 \mathrm{~S}_{0}, \mathrm{~S}_{10}$ 和 $\mathrm{S}_{80}$ 样品的 HRTEM 照片

Fig. 2. HRTEM images of $\mathrm{S}_{0}(\mathrm{a}, \mathrm{b}), \mathrm{S}_{10}(\mathrm{c})$, and $\mathrm{S}_{80}(\mathrm{~d})$ samples.

有典型的六方孔道结构. $\mathrm{S}_{0}$ 和 $\mathrm{S}_{10}$ 样品的 HRTEM 结果 (见图 2(b) 和 2(c)) 进一步证明了这一点. 随着 溶液中乙醇量的增加, 后面两个衍射峰逐渐减小并 最终消失, 说明介孔材料的有序性降低, $\mathrm{S}_{50}$ 和 $\mathrm{S}_{80}$ 样 品的孔道均变为蠕虫状结构 (见图 2(d)).

图 1(b) 是焙烧样品的 $\mathrm{N}_{2}$ 吸附-脱附等温线. 可 以看出, 所有样品的等温线均属 IUPAC 分类中的 IV 型, 是典型的介孔材料吸附曲线. 样品 $\mathrm{S}_{0}$ 和 $\mathrm{S}_{10}$ 在相对压力 $p / p_{0}=0.2 \sim 0.3$ 范围内有明显的毛细凝 聚现象, 表明乙醇用量在 $10 \mathrm{ml}$ 范围内得到的介孔 材料孔道较为规整, 没有明显的瓶颈效应, 孔径分布 较窄 (见图 1(c)); 而 $\mathrm{S}_{30}, \mathrm{~S}_{50}$ 和 $\mathrm{S}_{80}$ 样品等温线的滞 后环和孔径分布明显宽化, 与其有序性降低一致 (见 图 1(a)). 在相对压力 $p / p_{0}=0.95 \sim 1.0$ 范围内, $\mathrm{S}_{0}$ 样 品吸附量有所增加, 这是由颗粒间孔造成的. 由表 1 可见, 随着乙醇含量的增加, 样品的比表面积、孔体 积和孔径均有所减小; 但乙醇加入量达到 $80 \mathrm{ml}$ 时, 样品的比表面积反而增加.

\section{表 1 添加不同体积乙醇合成的样品的结构性质}

Table 1 Textural properties of the samples synthesized with different amounts of ethanol

\begin{tabular}{lccc}
\hline Sample & $A_{\mathrm{BET}} /\left(\mathrm{m}^{2} / \mathrm{g}\right)$ & Pore volume $\left(\mathrm{cm}^{3} / \mathrm{g}\right)$ & Pore diameter ${ }^{*}(D / \mathrm{nm})$ \\
\hline $\mathrm{S}_{0}$ & 965.0 & 0.90 & 2.41 \\
$\mathrm{~S}_{10}$ & 761.9 & 0.69 & 2.41 \\
$\mathrm{~S}_{30}$ & 770.4 & 0.79 & 2.41 \\
$\mathrm{~S}_{50}$ & 776.9 & 0.46 & 2.18 \\
$\mathrm{~S}_{80}$ & 1039.8 & 0.62 & 2.18 \\
\hline
\end{tabular}

*Calculated by the BJH method on the basis of the adsorption branch.
图 3 是不同乙醇添加量时所得样品的 SEM 照 片. 可以看出, $\mathrm{S}_{0}$ 样品的晶粒中虽然包括一些类柱 形和囊泡状颗粒, 但总体形貌为无定形; 而 $\mathrm{S}_{10}$ 样品 主要为类柱形; 当乙醇用量增加至 $30 \mathrm{ml}$ 时, 得到 囊泡和球状晶粒混合的产物; 继续增加乙醇用量至 $50 \mathrm{ml}$ 时, 晶粒变为新颖的葫芦状形貌; 当乙醇用量 达到 $80 \mathrm{ml}$ 时, 则得到了球状粒子, 且微球尺寸略大 于 $\mathrm{S}_{50}$ 晶粒. 由此可见, 样品形貌与乙醇加入量密切 相关.

因为 TEOS 在乙醇中溶解度较大, 所以乙醇的 加入降低了 TEOS 的水解速度, 从而造成溶液中带 电的硅粒子数目减少. 硅基介孔材料的形貌主要取 决于溶液中带负电硅胶束的聚合速度与介孔结构形 成速度之间的平衡. 当乙醇含量较低 $(10 \mathrm{ml})$ 时, 它 作为一种助表面活性剂, 主要进入胶束的内部, 这时 得到的样品仍为 MCM-41; 当乙醇含量升到 $50 \mathrm{ml}$ 时, 其主要起助溶剂的作用, 可降低溶液极性, 从而 形成球状结构. 继续增加乙醇含量, TEOS 的水解和 凝聚变得更为缓慢, 因而增加了介孔球之间的交联. 另外, 乙醇的疏水作用也会影响介孔相的形成.

合成体系中晶粒形貌的变化与文献中 ${ }^{[24]}$ 单独以 $\mathrm{CTAB}$ 为模板剂体系中的晶粒形貌的变化情况不同. 这是因为添加 NaPAA 的体系, 除了 CTAB 和低聚 态硅之间的静电作用以外, 长链的 NaPAA 也可以包 裹 $\mathrm{CTAB}$, 通过库仑力和静电作用在溶液中形成球 状囊泡, NaPAA/CTAB 球状囊泡被乙醇-水所形成的 油/水界面所平衡. 接着 $\mathrm{CTAB}$ 和低聚态硅之间的自 

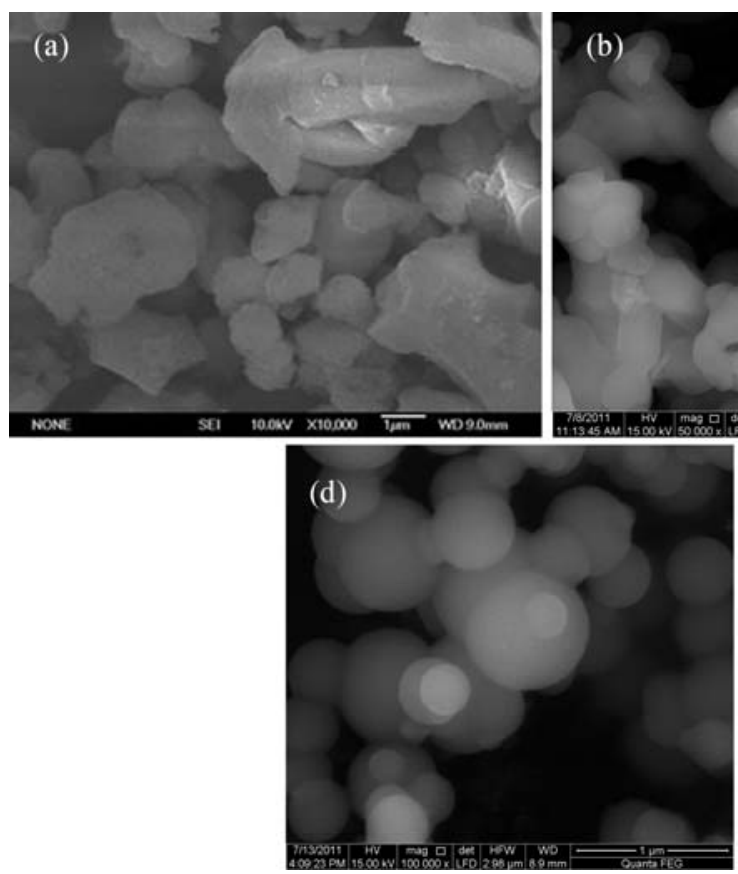

图 3 添加不同体积乙醇合成的样品的 SEM 照片

Fig. 3. SEM images of the samples synthesized with different amounts of ethanol. (a) $\mathrm{S}_{0}$; (b) $\mathrm{S}_{10}$; (c) $\mathrm{S}_{30}$; (d) $\mathrm{S}_{50}$; (e) $\mathrm{S}_{80}$.

组装在球状囊泡外围快速发生而形成复杂的纳米结 构. 由此可推测, 不同形貌的介孔材料可能是高分 子聚合物和乙醇共同作用的结果.

\section{2 晶化温度对样品结构和形貌的影响}

晶化温度对 TEOS 的水解和凝聚动力学的影响 很大, 因而也是决定产物结构和晶粒形貌的一个重 要因素. 图 4(a) 给出了 30,60 和 $85^{\circ} \mathrm{C}$ 合成的 $\mathrm{S}_{80}$ 样品的 XRD 谱. 可以看出, 所有样品都仅在 $2 \theta=$ $2.2^{\circ}$ 附近有一衍射峰, 表明具有蠕虫状孔道结构. 随 着晶化温度的升高, 该衍射峰逐渐增强, 表明升高晶 化温度有利于提高产物的有序度, 正如图 4(b) 和 (c)
所示, 不仅样品孔径分布变窄, 而且比表面积和孔体 积也明显增加 (见表 2), 说明中孔结构变得逐渐规 整. 文献[25]也发现较高温度和碱度有利于无定形 相重新溶解再组装为有序介孔相, 与本文结果一致.

表 2 不同晶化温度合成的 $\mathrm{S}_{80}$ 样品的结构性质

Table 2 Textural properties of the $\mathrm{S}_{80}$ samples synthesized at different temperature

\begin{tabular}{cccc}
\hline $\begin{array}{c}\text { Temperature } \\
\left({ }^{\circ} \mathrm{C}\right)\end{array}$ & $A_{\mathrm{BET}} /\left(\mathrm{m}^{2} / \mathrm{g}\right)$ & $\begin{array}{c}\text { Pore volume } \\
\left(\mathrm{cm}^{3} / \mathrm{g}\right)\end{array}$ & $\begin{array}{c}\text { Pore diameter } \\
(D / \mathrm{nm})\end{array}$ \\
\hline 30 & 821.3 & 0.49 & 2.03 \\
60 & 890.0 & 0.51 & 2.18 \\
85 & 1039.8 & 0.62 & 2.18 \\
\hline
\end{tabular}
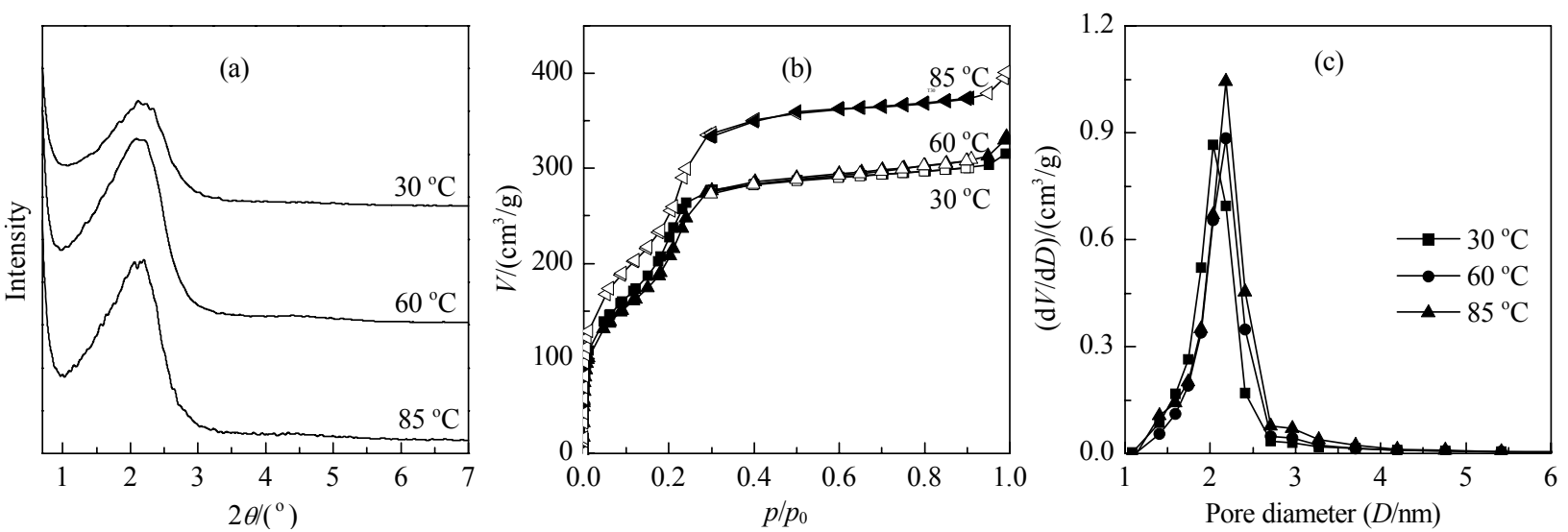

图 4 不同晶化温度合成的 $S_{80}$ 样品的 XRD 谱 (a), $N_{2}$ 吸附-脱附等温线 (b) 和孔径分布曲线 (c)

Fig. 4. XRD patterns (a), $\mathrm{N}_{2}$ adsorption-desorption isotherms (b), and pore size distribution curves (c) of the $\mathrm{S}_{80}$ samples synthesized at different temperature. 

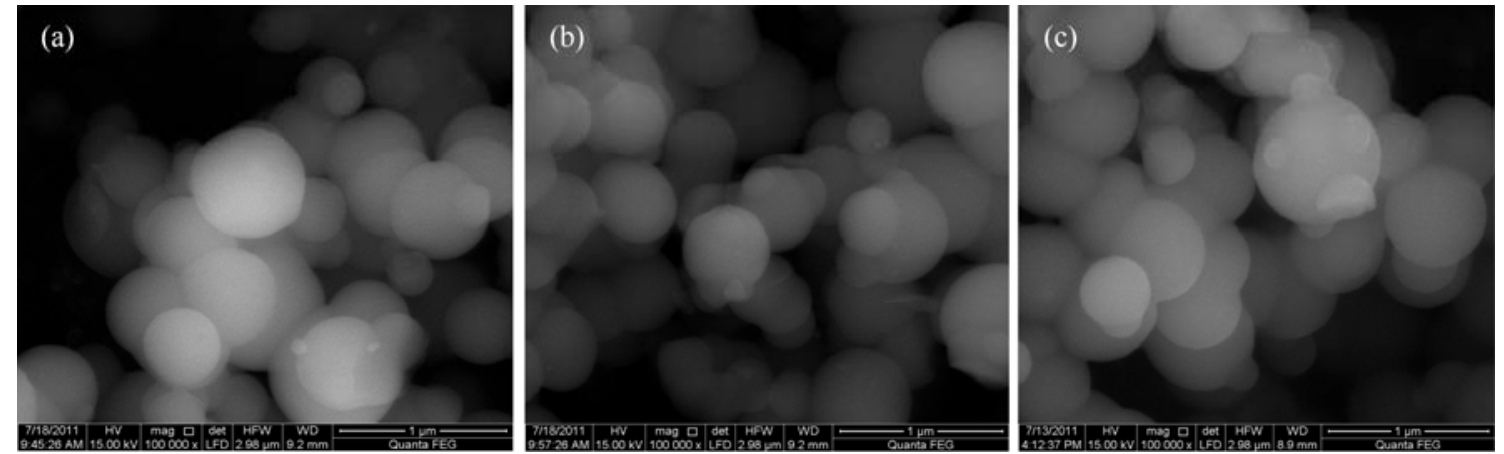

图 5 不同晶化温度合成的 $\mathrm{S}_{80}$ 样品的 SEM 照片

Fig. 5. SEM images of the $\mathrm{S}_{80}$ samples synthesized at different temperature. (a) $30^{\circ} \mathrm{C}$; (b) $60{ }^{\circ} \mathrm{C}$; (c) $85^{\circ} \mathrm{C}$.

图 5 为不同晶化温度所得 $\mathrm{S}_{80}$ 样品的 SEM 照 片. 由图可见, $30^{\circ} \mathrm{C}$ 时得到样品的晶粒尺寸约在 200 600 nm 之间.

\section{3 晶化时间对样品结构和形貌的影响}

图 6 为聚合物 NaPAA (分子量为 2100) 含量为 $0.05 \%$ 时于 $85^{\circ} \mathrm{C}$ 晶化不同时间所得 $\mathrm{S}_{80}$ 样品的 XRD 谱. 可以看出, 所有样品均只出现 (100) 面的 衍射峰, 未出现 (110) 和 (200) 晶面衍射峰, 说明样 品均具有蠕虫状孔道结构. 如表 3 所示, 当晶化时 间由 $2 \mathrm{~h}$ 延长至 $24 \mathrm{~h}$ 时, 样品的比表面积由 772.9

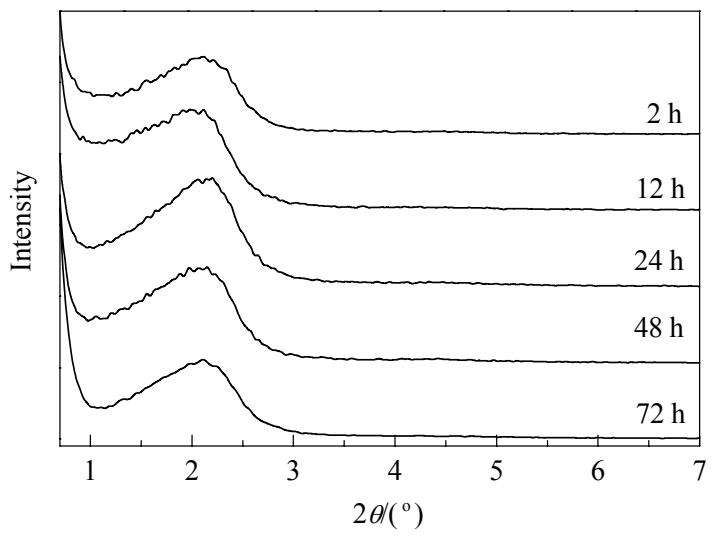

图 6 晶化不同时间所得 $\mathrm{S}_{80}$ 样品的 XRD 谱

Fig. 6. XRD patterns of the $S_{80}$ samples crystallized at $85^{\circ} \mathrm{C}$ for different time.

表 3 晶化不同时间所得 $\mathrm{S}_{80}$ 样品的结构性质

Table 3 Textural properties of the $\mathrm{S}_{80}$ samples crystallized at $85^{\circ} \mathrm{C}$ for different time

\begin{tabular}{cccc}
\hline $\begin{array}{c}\text { Crystallization } \\
\text { time }(\mathrm{h})\end{array}$ & $A_{\mathrm{BET}} /\left(\mathrm{m}^{2} / \mathrm{g}\right)$ & $\begin{array}{c}\text { Pore volume } \\
\left(\mathrm{cm}^{3} / \mathrm{g}\right)\end{array}$ & $\begin{array}{c}\text { Pore diameter } \\
(D / \mathrm{nm})\end{array}$ \\
\hline 2 & 772.9 & 0.53 & 2.18 \\
12 & 804.2 & 0.45 & 2.03 \\
24 & 1039.8 & 0.62 & 2.18 \\
48 & 805.3 & 0.47 & 2.18 \\
72 & 659.4 & 0.45 & 2.18 \\
\hline
\end{tabular}

$\mathrm{m}^{2} / \mathrm{g}$ 增加到 $1039.8 \mathrm{~m}^{2} / \mathrm{g}$, 孔体积由 $0.53 \mathrm{~cm}^{3} / \mathrm{g}$ 增加 到 $0.62 \mathrm{~cm}^{3} / \mathrm{g}$, 进一步延长晶化时间, 样品的比表面 积和孔体积反而减小.

图 7 为晶化不同时间所得样品的 SEM 照片. 可以看出, 所有样品的晶粒均呈球形, 但晶化 $12 \mathrm{~h}$ 得到的部分样品颗粒有半圆形缺口。随着晶化时间 的延长, 半圆形缺口晶粒减少, 绝大多数晶粒变成较 为完美的硅球, 且晶粒尺寸有所增加, 但晶化超过 $48 \mathrm{~h}$ 时, 样品比表面积减小.

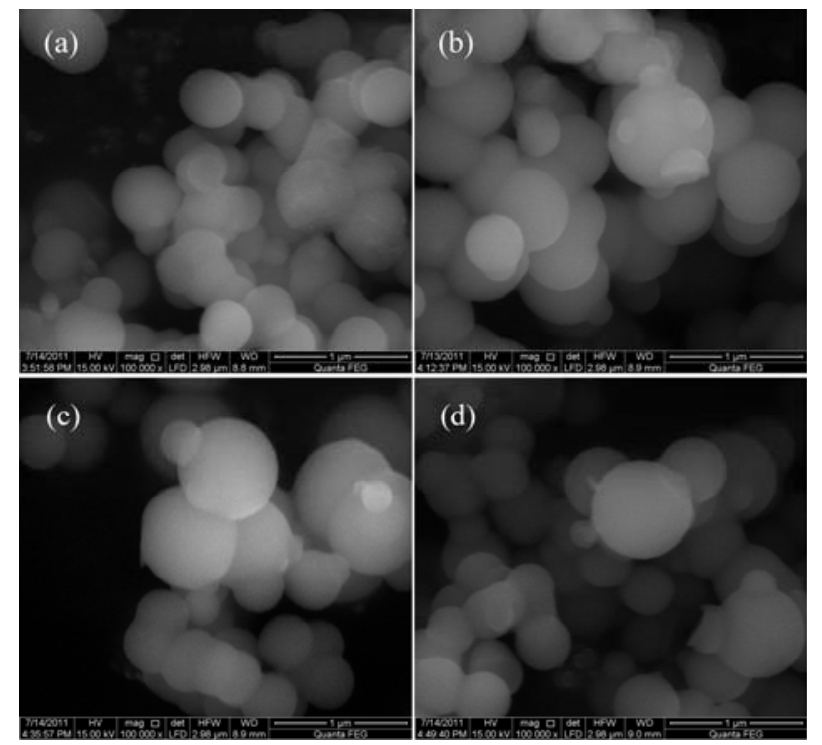

图 7 晶化不同时间所得 $\mathrm{S}_{80}$ 样品的 SEM 照片

Fig. 7. SEM images of the $\mathrm{S}_{80}$ samples crystallized at $85{ }^{\circ} \mathrm{C}$ for different time. (a) $12 \mathrm{~h}$; (b) $24 \mathrm{~h}$; (c) $48 \mathrm{~h}$; (d) $72 \mathrm{~h}$.

\subsection{NaPAA 含量对样品结构和形貌的影响}

在异丙醇-水体系中, 阴离子聚合物 PAA 可用 作助模板剂合成复合介孔材料 ${ }^{[20]}$, 通过调变 PAA/ CTAB 质量比, 可以得到多种形貌新颖、尺寸均匀的 介孔硅颗粒. 图 8 为不同 NaPAA (分子量为 2100) 


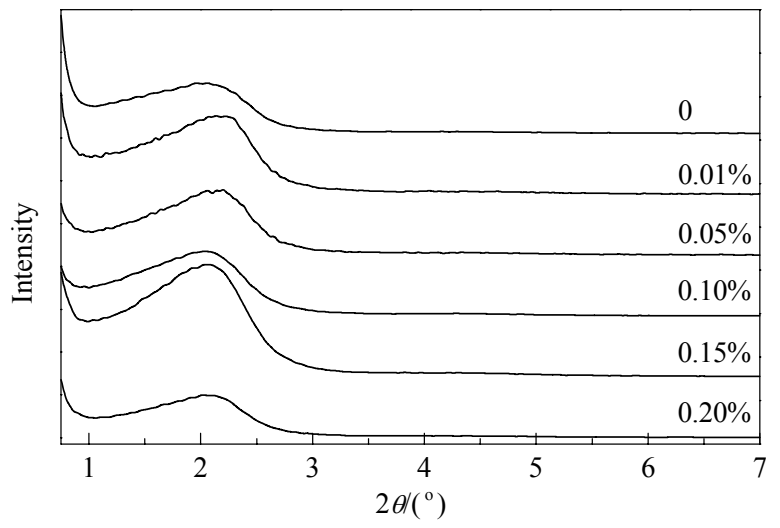

图 8 不同 NaPAA 用量所得 $\mathrm{S}_{80}$ 样品的 XRD 谱

Fig. 8. XRD patterns of the $S_{80}$ samples obtained at different NaPAA content.

浓度时于 $85^{\circ} \mathrm{C}$ 晶化 $24 \mathrm{~h}$ 所得 $\mathrm{S}_{80}$ 样品焙烧后的 XRD 谱. 虽然所有样品均在 $2 \theta=2.1^{\circ}$ 附近呈现一宽 的衍射峰, 但孔径分布很窄, 说明介孔孔径较为均 匀. 增加 NaPAA 浓度, 样品比表面积增加, 但当水 溶液中 NaPAA 含量高于 $0.05 \%$ 时, 所得样品比表 面积却大幅减小 (见表 4).

图 9 为上述样品的 SEM 照片. 可以看出, 当 NaPAA 添加量小于 $0.05 \%$ 时, 虽然颗粒尺寸有所增 加, 但对其形貌没有影响; 将 NaPPA 添加量提高至 $0.10 \%$ 时, 不仅生成葫芦状晶粒, 而且半圆形缺口颗 粒也明显增多. 体系中加入 NaPAA 后, 由于高分子
表 4 不同 NaPAA 用量所得 $\mathrm{S}_{80}$ 样品的结构性质

Table 4 Textural properties of the $\mathrm{S}_{80}$ samples obtained at different NaPAA content

\begin{tabular}{cccc}
\hline $\begin{array}{c}\text { NaPAA } \\
\text { concentration (\%) }\end{array}$ & $A_{\mathrm{BET}} /\left(\mathrm{m}^{2} / \mathrm{g}\right)$ & $\begin{array}{c}\text { Pore volume } \\
\left(\mathrm{cm}^{3} / \mathrm{g}\right)\end{array}$ & $\begin{array}{c}\text { Pore diameter } \\
(D / \mathrm{nm})\end{array}$ \\
\hline 0 & 676.3 & 0.44 & 2.18 \\
0.01 & 837.7 & 0.48 & 2.18 \\
0.05 & 1039.8 & 0.62 & 2.18 \\
0.10 & 725.5 & 0.40 & 2.18 \\
0.15 & 700.1 & 0.50 & 2.18 \\
0.20 & 694.8 & 0.46 & 2.18 \\
\hline
\end{tabular}

离子态 $\mathrm{PAA}$ 的静电斥力, 溶液中形成的 $\mathrm{Na}-$ $\mathrm{PAA} / \mathrm{CTAB}$ 球状胶束聚集体经历一个体积溶胀过 程. 随着反应的进行, 乙醇逐渐从 NaPAA/CTAB 球 状胶束表面溢出, 破坏了胶束表面层的稳定性, TEOS 水解后形成的硅酸根离子在胶束表面层缠绕, 造成整个反应体系体积增大, 产物颗粒尺寸形成较 大. NaPAA 用量过多, 溶胀幅度增加, 致使球形颗粒 爆裂, 形成较多的半圆形缺口颗粒.

\subsection{NaPPA 分子量对样品结构和形貌的影响}

聚合物相对分子量不同, 其性质也明显不同. 为此, 我们在 NaPAA 添加量为 $0.05 \%$ 于 $85^{\circ} \mathrm{C}$ 晶 化 $24 \mathrm{~h}$ 条件下, 考察了 $\mathrm{NaPAA}$ 分子量对 $\mathrm{S}_{80}$ 结构和 晶粒形貌的影响. 如图 10 所示, 所有样品均只在 $2 \theta$ $=2.2^{\circ}$ 处有一宽峰, 表明 NaPAA 分子量对产物结构 的有序性影响不大. 但提高 NaPAA 分子量, 所得样
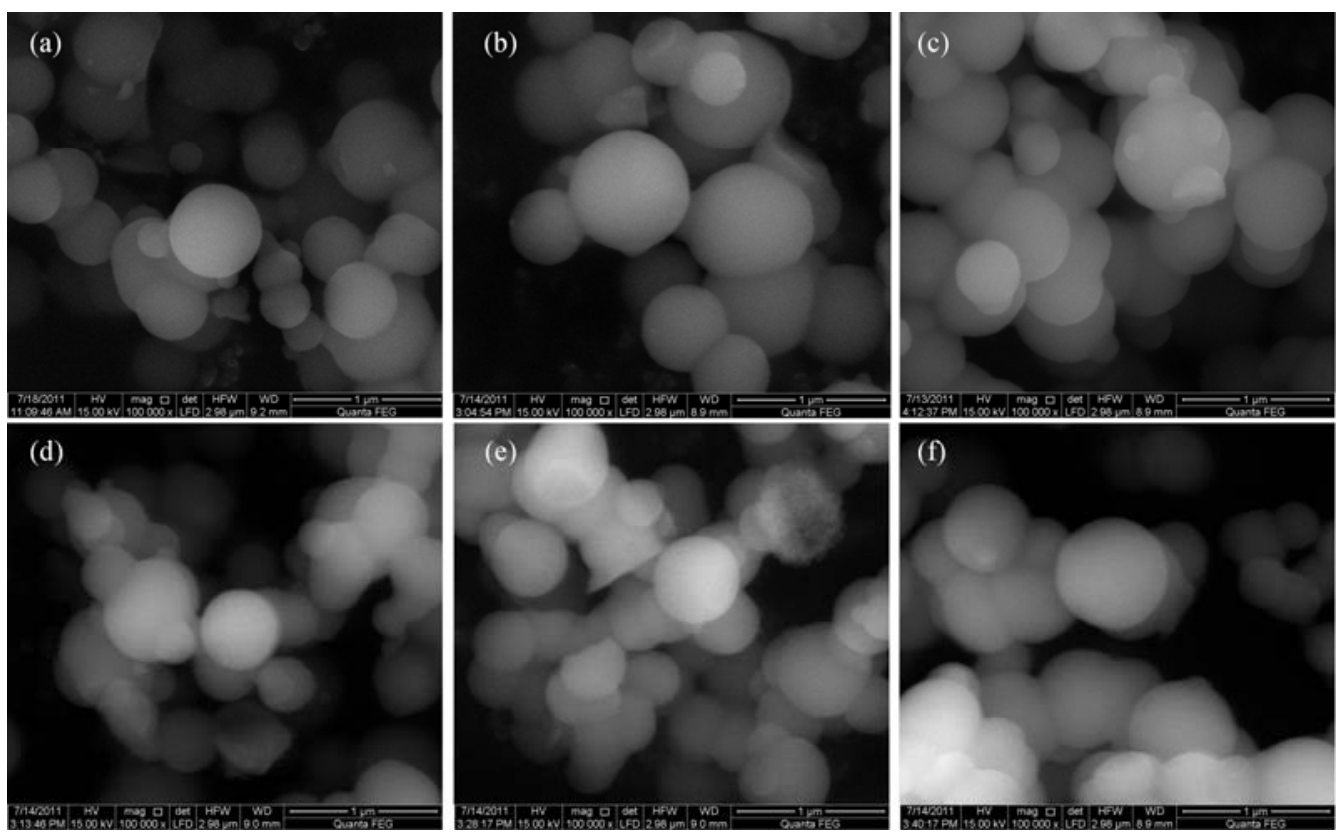

图 9 不同 NaPAA 用量所得 $S_{80}$ 样品的 SEM 照片

Fig. 9. SEM images of the $\mathrm{S}_{80}$ samples obtained at different NaPAA content. (a) 0 ; (b) $0.01 \%$; (c) $0.05 \%$; (d) $0.10 \%$; (e) $0.15 \%$; (f) $0.20 \%$. 


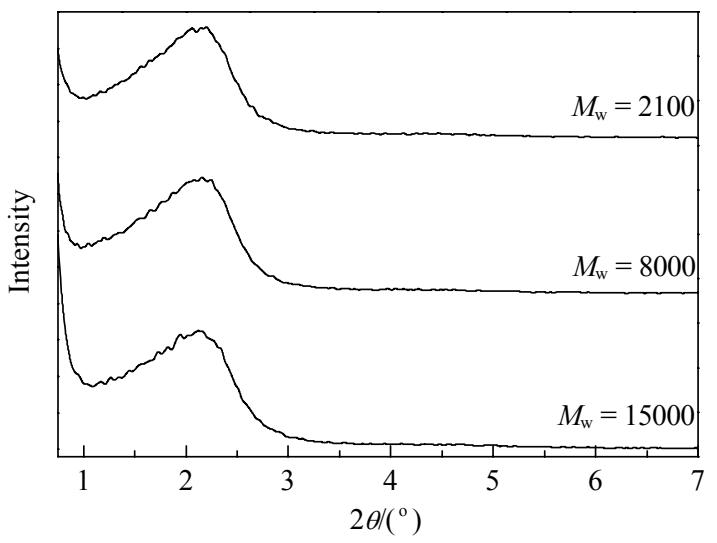

图 10 添加不同分子量 NaPAA 得到的 $\mathrm{S}_{80}$ 样品的 XRD 谱 Fig. 10. XRD patterns of the $S_{80}$ samples obtained at different NaPAA molecular weight.

品比表面积和孔体积大幅增加 (见表 5).

图 11 为上述样品的 SEM 照片. 由图可见, 随 着 NaPPA 分子量的增加, 所得样品中球状颗粒分散 性有所增加, 这可能是由于 $\mathrm{NaPAA}$ 分子量越大, 链 长越长, 对 $\mathrm{CTAB}$ 包裹作用越紧密, 形成的 $\mathrm{Na}-$ $\mathrm{PAA} / \mathrm{CTAB}$ 聚集体变得相对孤立, 从而导致颗粒分
表 5 添加不同分子量 NaPAA 得到的 $\mathrm{S}_{80}$ 样品的结构性质

Table 5 Textural properties of the $S_{80}$ samples obtained at different NaPAA molecular weight

\begin{tabular}{cccc}
\hline $\begin{array}{c}\text { NaPAA } \\
\text { molecular weight }\end{array}$ & $A_{\mathrm{BEE}} /\left(\mathrm{m}^{2} / \mathrm{g}\right)$ & $\begin{array}{c}\text { Pore volume } \\
\left(\mathrm{cm}^{3} / \mathrm{g}\right)\end{array}$ & $\begin{array}{c}\text { Pore diameter } \\
(D / \mathrm{nm})\end{array}$ \\
\hline 2100 & 821.2 & 0.49 & 2.03 \\
8000 & 833.6 & 0.54 & 2.03 \\
15000 & 1487.5 & 0.69 & 2.03 \\
\hline
\end{tabular}

散性增加.

\section{3 结论}

以阳离子表面活性剂 CTAB 和阴离子水溶性聚 合物 NaPAA 混合物为模板剂, 乙醇为分散剂, 氨水 为催化剂, 正硅酸乙酯为前驱体, 通过调变乙醇和 NaPAA 用量, 利用 Stöber 方法可制备出结构为一维 六方和蠕虫状, 晶粒形貌为无定形、类柱状、囊泡状、 葫芦状和球状的硅基介孔材料。适度提高晶化温度 和延长晶化时间有利于提高介孔材料的有序度, 增 加 NaPAA 分子量可以大幅提高球状介孔材料的比 表面积和孔体积.
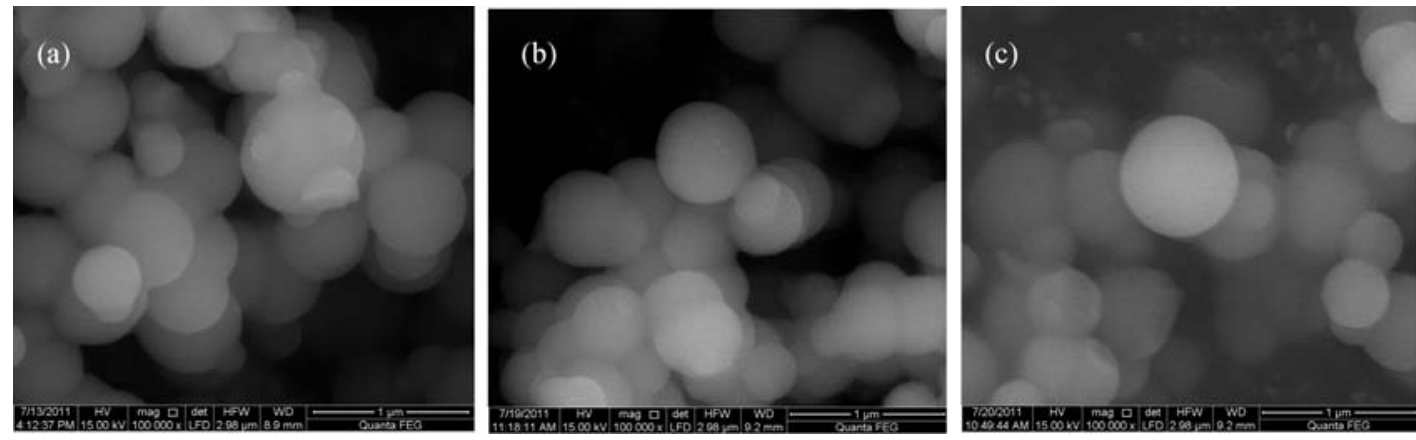

图 11 添加不同分子量 NaPAA 得到的 $\mathrm{S}_{80}$ 样品的 SEM 照片

Fig. 11. SEM images of the $\mathrm{S}_{80}$ samples obtained at different NaPAA molecular weight. (a) 2100; (b) 8000; (c) 15000 .

\section{参考文献}

1 Beck J S, Vartuli J C, Roth W J, Leonowicz M E, Kresge C T, Schmitt K D, Chu C T W, Olson D H, Sheppard E W. $J$ Am Chem Soc, 1992, 114: 10834

2 Kresge C T, Leonowicz M E, Roth W J, Vartuli J C, Beck J S. Nature, 1992, 359: 710

3 Selvam P, Bhatia S K, Sonwane C G. Ind Eng Chem Res, 2001, 40: 3237

4 Linssen T, Cassiers K, Cool P, Vansant E F. Adv Colloid Interface Sci, 2003, 103: 121

5 Liu X B, Li L S, Du Y, Guo Z, Ong T T, Chen Y, Ng S C, Yang Y H. J Chromatogr A, 2009, 1216: 7767

6 Li Y Y, Cheng S Y, Dai P C, Liang X M, Ke Y X. Chem Commun, 2009: 1085
7 冯雪风, 金卫根, 刘芬, 罗建勋. 无机盐工业 (Feng X F, Jin W G, Liu F, Luo J X. Inorg Chem Ind), 2008, 40(12): 12

8 Zhao D Y, Feng J L, Huo Q S, Melosh N, Fredrickson G H, Chmelka B F, Stucky G D. Science, 1998, 279: 548

9 Jin Z W, Wang X D, Cui X G. Colloids Surf A, 2008, 316: 27

10 Suzuki K, Ikari K, Imai H. J Am Chem Soc, 2004, 126: 462

11 Ye J F, Zhang H J, Yang R, Li X G, Qi L M. Small, 2010, 6: 296

12 Liu Y R. Microporous Mesoporous Mater, 2009, 124: 190

13 Braga T P, Gomes E C C, de Sousa A F, Carreño N L V, Longhinotti E, Valentini A. J Non-Crystal Solids, 2009, 355: 860

14 Lin H M, Zhu G H, Xing J J, Gao B, Qiu S L. Langmuir, 2009, 25: 10159 
15 Wang Y, Song H H, Zhang H, Liao L F, Liu N, Chen X H. J Mater Chem, 2011, 21: 5576

16 Chen Q R, Han L, Gao C B, Che S A. Microporous Mesoporous Mater, 2010, 128: 203

17 Gu X, Li C L, Liu X H, Ren J W, Wang Y Q, Guo Y L, Guo Y, Lu G Z. J Phys Chem C, 2009, 113: 6472

18 Li Y, Bi L F, Wang S B, Chen Y L, Li B Z, Zhu X L, Yang Y G. Chem Commun, 2010, 46: 2680

19 Niu D C, Ma Z, Li Y S, Shi J L. J Am Chem Soc, 2010, 132: 15144

20 Guo X H, Deng Y H, Tu B, Zhao D Y. Langmuir, 2010, 26: 702

21 Chen H M, He J H, Tang H M, Yan C X. Chem Mater, 2008, 20: 5894

22 Yu S H, Cölfen H. J Mater Chem, 2004, 14: 2124

23 Pouget E, Dujardin E, Cavalier A, Moreac A, Valery C, Marchi-Artzner V, Weiss T, Renault A, Paternoster M, Artzner F. Nature Mater, 2007, 6: 434

24 Liu S Q, Cool P, Collart O, Van Der Voort P, Vansant E F, Lebedev O I, Van Tendeloo G, Jiang M H. J Phys Chem B, 2003, 107: 10405

25 Iler R K. The Chemistry of Silica. New York: Wiley-Interscience Publications, 1979

\section{英 译 文 \\ English Text}

Mesoporous materials have been applied in adsorption-separation, catalysis, biochemistry, chromatography, and drug delivery ever since M41S materials were synthesized $[1,2]$. This is largely due to their large surface areas and pore volumes, tunable pore sizes, and uniform pore size distributions [3-7]. The properties of mesoporous materials are not only dependent on their inner pore structures but also closely related to their macroscopic structure and microcosmic morphology. Template structure and synthetic conditions are the key factors that affect the pore structure, the order, and the morphology of mesoporous materials. Therefore, optimization of template and choice of synthetic conditions play a major role in the synthesis of mesoporous materials. However, traditional anionic, cationic, or neutral surfactants are still being used as templates to synthesize ordered mesoporous materials. Although there are a variety of commercially available surfactants, only selected few can be used as templates to synthesize mesoporous materials [3]. This limits the structures and applications of mesoporous materials. Therefore, it is imperative that new and improved templates are used to synthesize mesoporous materials. Thus, single-phase [8-11], composite [12] and natural copolymers [13], copolymer-surfactant complex [14,15], Gemini surfactant [16], fluorocarbon surfactant [17], and chiral alcohols [18] have been applied to the synthesis of mesoporous materials. In addition, various auxiliary agents, such as ethanol, isopropanol, ether, and acetone, have also been introduced to the synthetic system in order to control the structures and morphologies of mesoporous materials [16,19-21].

Anionic water-soluble poly(acrylic acid) (PAA) has been used in the biomineralization process because it possesses strong hydrophilic carbonyl groups [22]. Recent research indicates that amorphous silica particles can be obtained by a combination of polyaminoamide dendrimers and PAA molecules [23]. Guo et al. [20] have synthesized mesoporous silica particles with controllable cavities in their surface in mixed water-isopropanol solvent at room temperature using PAA and cationic cetyltrimethylammonium bromide (CTAB) as dual templates. However, limited methodologies are developed in the synthesis of mesoporous silica particles at high temperature in the presence of organic solvent. In this work, a mixture of CTAB and anionic water-soluble sodium polyacrylate (NaPAA) is used as template to synthesize spherical mesoporous materials at high temperature in the presence of ethanol solvent. The effects of synthetic conditions on the formation of the final products are also investigated.

\section{Experimental}

\subsection{Synthesis of samples}

In a typical synthesis, an appropriate amount of CTAB ( $\geq$ 99.0\%, J\&K Scientific Ltd.) was dissolved in aqueous solution (molar ratio $\mathrm{CTAB} / \mathrm{SiO}_{2}=0.13, \mathrm{NH}_{4}{ }^{+} / \mathrm{SiO}_{2}=7.3, \mathrm{H}_{2} \mathrm{O} /$ $\mathrm{SiO}_{2}=130$ ), which contained $13.6 \mathrm{ml}$ of ammonia solution $(25 \%)$. The mixture was vigorously stirred at $30{ }^{\circ} \mathrm{C}$ for $0.5 \mathrm{~h}$. Then, a desired amount of $\operatorname{NaPAA}\left(M_{\mathrm{w}}=2100,0-0.2 \%\right)$ was added. After stirring for $1 \mathrm{~h}$, a certain amount of ethanol was added and stirred for additional $0.5 \mathrm{~h}$ to form a homogeneous solution. Finally, an appropriate amount of tetraethyl orthosilicate (TEOS) was added quickly into the above solution and sustained for $1 \mathrm{~h}$ at $30{ }^{\circ} \mathrm{C}$. The mixture was further stirred at $85^{\circ} \mathrm{C}$ for another $24 \mathrm{~h}$. The resultant products were collected by filtration, and the residue was washed, dried, and calcined at $550{ }^{\circ} \mathrm{C}$ for $6 \mathrm{~h}$ to remove organic templates. According to the ethanol amount, the obtained samples are denoted as $\mathrm{S}_{x}$ with $x$ representing the ethanol volume $(\mathrm{ml})$.

\subsection{Characterization of samples}

The structures of the products were identified by a Bruker D8 ADVANCE X-ray diffractometer (XRD) with $\mathrm{Cu} K_{\alpha}$ radiation at $40 \mathrm{kV}$ and $40 \mathrm{~mA}$. High-resolution transmission electron microscopy (HRTEM) was performed on a JEOL-2100 microscope. Nitrogen adsorption-desorption isotherms were measured on a Belsorp-Max sorption analyzer. Samples were degassed at $300{ }^{\circ} \mathrm{C}$ under high vacuum conditions for $6 \mathrm{~h}$ before measurements. The surface areas 
were calculated by the BET (Brunauer-Emmett-Teller) method, and the pore size distributions and pore volumes were calculated by the BJH (Barrett-Joyner-Halenda) method. Scanning electron microscopy (SEM) images were recorded on a QUANTA 400F microscope.

\section{Results and discussion}

\subsection{Effect of ethanol amounts on the structures and morphologies of the samples}

The XRD patterns of the calcined samples synthesized with different amounts of ethanol are shown in Fig. 1(a). It can be seen that $\mathrm{S}_{0}$ and $\mathrm{S}_{10}$ exhibit three well-resolved peaks at approximately $2 \theta=2^{\circ}, 4.1^{\circ}$, and $4.7^{\circ}$, respectively. These peaks are indexed to the (100), (110), and (200) reflections of 2D-hexagonal $\mathrm{p} 6 \mathrm{~mm}$ mesostructure. This point is in good agreement with the TEM observation (Fig. 2(b) and (c)). As the amount of ethanol increases, the intensities of (110) and (200) peaks significantly decreased, indicative of a considerable decrease in the order of mesoporous silicas. Thus, $\mathrm{S}_{50}$ and $\mathrm{S}_{80}$ showed a worm-like structure (Fig. 2(d)).

The $\mathrm{N}_{2}$ adsorption-desorption isotherms of the calcined samples are shown in Fig. 1(b). All samples exhibit the usual type IV isotherms, indicating the formation of mesostructure samples. It is clear that $\mathrm{S}_{0}$ and $\mathrm{S}_{10}$ have a capillary condensation at a relative pressure of $p / p_{0}$ between 0.2 and 0.3 , indicating that the pore structures of the prepared samples are regular. Consequently, these two samples gave narrow pore size distributions (Fig. 1(c)). However, the hysteresis loops and pore size distributions of samples obviously widened when the ethanol amount is more than $30 \mathrm{ml}$. This is in agreement with the decrease in the order of the samples (Fig. 1(a)). A slight increase in the adsorption amount of $S_{0}$ in the $p / p_{0}$ of $0.95-1.0$ is assigned to the voids among particles. Table 1 shows that the surface area, pore diameter, and volume decrease with increasing ethanol amount. Nevertheless, a considerable increase in the surface area was observed for the sample of $S_{80}$.

Figure 3 shows the SEM images of the samples synthesized with different amounts of ethanol. $\mathrm{S}_{0}$ has three kinds of morphology: column, vesicle, and amorphous material (Fig. 2(a)). The columnar particles are dominant in $S_{10}$, while $S_{30}$ consists of vesicles and spherical particles. In contrast, novel cucurbit-like particles were formed when the ethanol amount was increased to $50 \mathrm{ml}$. A further increase in the ethanol amount to $80 \mathrm{ml}$ mainly led to the formation of spherical particles, the sizes of which are slightly larger than those of $\mathrm{S}_{50}$. This shows that the ethanol amounts added to the synthetic gels have a great effect on the morphologies of the formed mesoporous silicas.

Because the solubility of TEOS in ethanol is much higher than that in water, addition of ethanol to the synthetic gel will definitely slow down the hydrolysis rate of TEOS, resulting in a decrease of charged silicate particles in the solution. It is well known that the morphology of a growing particle mainly depends on the balance between the polymerization rate of the charged silicate particles and the formation rate of mesoporous structure. When the ethanol amount in the solution is about $10 \mathrm{ml}$, most of the organic molecules, as co-surfactants incorporate into micelles, and thus, the structure formed still has 2D-hexagonal p6mm (MCM-41). However, when the ethanol amount in the solution was increased to $50 \mathrm{ml}$, the ethanol will also act as a co-solvent, leading to a sharp decrease in the polarity of the solution and consequently the transformation of the hexagonal structure to the worm-like one. As the ethanol amount is continuously increased, this further weakens the hydrolysis rate of TEOS and condensation rate of silicate species, which would result in the adhesion of spheres to each other. In addition, the hydrophobic interaction of ethanol might affect the structures and morphologies of the formed mesoporous silicas as well.

The crystal morphology obtained in the present system containing NaPAA polymer is quite different from that obtained in the system with CTAB as the sole template [24]. The long hydrophobic chain of NaPAA could bind to the CTAB molecules through electrostatic and hydrophobic interactions and form spherical vesicles in the solution. The formed NaPAA/CTAB spherical vesicles can be stabilized by an oil/water interface formed in ethanol-water system. In particular, the self-assembly between CTAB and silica oligomers might quickly occur around the spherical vesicles, leading to the formation of particles with complicated nano-architecture. From the above studies, it could be deduced that the different morphologies of the samples obtained in the present system are as a result of addition of both polymer and ethanol to the synthetic gel.

\subsection{Effect of crystallization temperature on the structures and morphologies of the samples}

The kinetics of the hydrolysis of TEOS and condensation rates of silicate species are highly dependent on the crystallization temperature, which, hence, is a key factor in determining the structures and morphologies of particles. Figure 4(a) shows the XRD patterns of $\mathrm{S}_{80}$ samples synthesized at 30,60 , and $85^{\circ} \mathrm{C}$. Clearly, all samples exhibit only one diffraction peak at the $2 \theta$ of $2.2^{\circ}$, indicating that they all have worm-like mesostructures. The diffraction peaks of these samples increased in intensity with increasing crystallization temperature, suggesting that high crystallization temperature is favorable for the increase in the order of mesostructure, giving a narrow pore size distribution and a high surface area and pore volume (Fig. 4(b) and (c), Table 2). This shows that 
higher temperature is beneficial to the dissolution and reorganization of the amorphous synthetic gel [25]. Figure 5 shows that the diameter of the sample particle synthesized at $30{ }^{\circ} \mathrm{C}$ is in the range from 200 to $600 \mathrm{~nm}$.

\subsection{Effect of crystallization time on the structures and morphologies of the samples}

Figure 6 shows the XRD patterns of the $\mathrm{S}_{80}$ samples crystallized at $85{ }^{\circ} \mathrm{C}$ for different time. The concentration of polymer NaPAA (molecular weight $=2100$ ) in the synthetic gel is $0.05 \%$. All samples have only one diffraction peak assigned to (100) facet, indicative of a worm-like structure. Table 3 shows that the surface area and the pore volume of the samples increased from 772.9 to $1039.8 \mathrm{~m}^{2} / \mathrm{g}$ and from 0.53 to $0.62 \mathrm{~cm}^{3} / \mathrm{g}$, respectively, when the crystallization time was increased from 2 to $24 \mathrm{~h}$. However, a further increase in the crystallization time led to a gradual decrease in the surface areas and pore volumes of the samples (Table 3). Figure 7 shows that all samples exhibit spherical morphology although some samples collected at $12 \mathrm{~h}$ contain semispherical particles, the number of which decreased with increasing crystallization time.

\subsection{Effect of polymer content on the structures and morphologies of the samples}

The anionic polymer of PAA could act as a co-template to direct the formation of hierarchical mesoporous materials in an isopropanol-water system [20]. By changing the mass ratios of PAA to CTAB, uniform mesoporous silica particles with various morphologies have been fabricated. Figure 8 shows the XRD patterns of the calcined $\mathrm{S}_{80}$ samples crystallized at $85{ }^{\circ} \mathrm{C}$ for $24 \mathrm{~h}$ in the presence of different amounts of NaPAA (molecular weight $=2100$ ). Although all samples have only one broad diffraction peak at $2 \theta$ of $2.1^{\circ}$, their pore size distributions are very narrow, indicative of a uniform mesoporous structure. Table 4 shows that their surface areas gradually increased with increasing NaPAA content up to $0.05 \%$. Nevertheless, a further increase in the NaPAA amount contrarily resulted in a decrease in the surface area.

Figure 9 shows the SEM images of the $\mathrm{S}_{80}$ samples synthesized at different NaPPA concentrations. Although the particle sizes of the samples slightly increased with increasing NaPAA content when it is less than $0.05 \%$, the particle morphologies are similar. Nevertheless, semispherical particles increased and a number of cucurbit-like particles are formed when the content of NaPAA was increased to $0.10 \%$. After addition of NaPAA, the NaPAA/CTAB spherical aggregates might be formed and swollen because of the elec- trostatic repulsion of the ionized PAA macromolecules. This leads to a gradual escape of ethanol from the NaPAA/CTAB spherical micelle interface, destroying stability of the interface layer of the micelle. In addition, the silicate species formed from hydrolysis of TEOS surround the interface of the micelle. This resulted in a great increase in the particle size, and the higher the NaPAA concentration is, the higher the increase degree is. Thus, the rupture of spherical particles occurred, forming semispherical particles.

\subsection{Effect of NaPAA molecular weight on the structures and morphologies of the samples}

The properties of polymer are dependent on its molecular weight. Therefore, the effect of NaPAA molecular weight on the structures and morphologies of $\mathrm{S}_{80}$ samples were further investigated. The crystallization temperature, crystallization time, and the content of NaPAA were kept at $85^{\circ} \mathrm{C}, 24 \mathrm{~h}$, and $0.05 \%$, respectively. Figure 10 indicates that the molecular weight of NaPAA has no obvious effect on the order of samples. All samples exhibit only one broad peak at $2 \theta$ of $2.2^{\circ}$ in their XRD patterns. Table 5 shows that the surface areas and pore volumes of the samples increased with increase in NaPAA molecular weights. Figure 11 shows that the aggregation degree of spherical particles decreased with increasing NaPPA molecular weight. This may be because large NaPAA molecules would tightly encircle CTAB, leading to somehow isolation of the formed NaPAA/CTAB aggregates, and consequently, to the increase of particle dispersion.

\section{Conclusions}

A series of mesoporous silicas have been synthesized using the Stöber method with mixtures of cationic CTAB and water-soluble anionic NaPAA as template, ethanol as dispersant, ammonia as catalyst, and TEOS as silica precursor. The structures and morphologies of the samples depend on the NaPAA and ethanol amount. By adjusting the amount of ethanol and NaPAA, 2D hexagonal and worm-like mosporous silicas with amorphous, columnar, vesicle, cucurbit-like, and spherical morphologies can be obtained. High crystallization temperature and long crystallization time are favorable to the formation of highly ordered mesoporous silicas. The surface areas and pore volumes of the spherical samples considerably increase with the increase in NaPAA molecular weight.

Full-text paper available online at Elsevier ScienceDirect http://www.sciencedirect.com/science/journal/18722067 